\title{
Chapter 39 \\ Article 40: The Rights in the Juvenile Justice Setting
}

\author{
Roberta Ruggiero
}

1. States Parties recognize the right of every child alleged as, accused of, or recognized as having infringed the penal law to be treated in a manner consistent with the promotion of the child's sense of dignity and worth, which reinforces the child's respect for the human rights and fundamental freedoms of others and which takes into account the child's age and the desirability of promoting the child's reintegration and the child's assuming a constructive role in society.

2. To this end, and having regard to the relevant provisions of international instruments, States Parties shall, in particular, ensure that:

(a) No child shall be alleged as, be accused of, or recognized as having infringed the penal law by reason of acts or omissions that were not prohibited by national or international law at the time they were committed;

(b) Every child alleged as or accused of having infringed the penal law has at least the following guarantees:

(i) To be presumed innocent until proven guilty according to law;

(ii) To be informed promptly and directly of the charges against him or her, and, if appropriate, through his or her parents or legal guardians, and to have legal or other appropriate assistance in the preparation and presentation of his or her defence;

(continued)

R. Ruggiero ( $\triangle)$

Centre for Children's Rights Studies, University of Geneva, Geneva, Switzerland

e-mail: roberta.ruggiero@unige.ch 
(iii) To have the matter determined without delay by a competent, independent and impartial authority or judicial body in a fair hearing according to law, in the presence of legal or other appropriate assistance and, unless it is considered not to be in the best interest of the child, in particular, taking into account his or her age or situation, his or her parents or legal guardians;

(iv) Not to be compelled to give testimony or to confess guilt; to examine or have examined adverse witnesses and to obtain the participation and examination of witnesses on his or her behalf under conditions of equality;

(v) If considered to have infringed the penal law, to have this decision and any measures imposed in consequence thereof reviewed by a higher competent, independent and impartial authority or judicial body according to law;

(vi) To have the free assistance of an interpreter if the child cannot understand or speak the language used;

(vii) To have his or her privacy fully respected at all stages of the proceedings.

3. States Parties shall seek to promote the establishment of laws, procedures, authorities and institutions specifically applicable to children alleged as, accused of, or recognized as having infringed the penal law, and, in particular:

(a) The establishment of a minimum age below which children shall be presumed not to have the capacity to infringe the penal law;

(b) Whenever appropriate and desirable, measures for dealing with such children without resorting to judicial proceedings, providing that human rights and legal safeguards are fully respected.

4. A variety of dispositions, such as care, guidance and supervision orders; counselling; probation; foster care; education and vocational training programmes and other alternatives to institutional care shall be available to ensure that children are dealt with in a manner appropriate to their wellbeing and proportionate both to their circumstances and the offence.

\section{What Did Children Say?}

'There should be visits in cells, do activities to know the rights because the children there are already stressed. A real human that walks around the cells.' (Western Europe/Other). 
Government to build a training camp where child who may be convicted, sentenced for short time will do their time in prison and by the end of their jail term, and they will come out as a changed person. They need government to provide them with trained and qualify lawyers that will be looking into the case of juvenile. (Africa).

\section{Overview}

Article 40 imposes a child rights-based approach to juvenile criminal justice, with the objective of setting up a comprehensive and autonomous juvenile justice policy. Based on the General Comment no. 24, this policy should establish the minimum age of criminal responsibility and include measures to prevent children's offending behaviour. It should also focus upon the rehabilitation and reintegration of children in conflict with the law into society (UN Committee on the Rights of the Child, 2007a, paras. 2, 3, 10, 2019, paras. 17, 22,28; van Bueren, 2005, pp. 1-3). With the adoption of Article 40, the concept of the child's well-being and best interests become aspects of basic concern in the administration of juvenile justice. The specific physical, psychological, development, and educational needs of the child justify this requirement for a specialised juvenile justice system and the replacement of the traditional objectives of criminal justice repression and retribution, with 'rehabilitation and restorative justice objectives' (UN Committee on the Rights of the Child, 2007a, paras. 2-3, 10, 2019, paras. 22, 28).

Article 40 concerns the rights of all children alleged as, accused of, or recognised as having infringed the penal law, from the moment a complaint is made, through the investigation phase, the arrest, and the accusation, to the pre-trial period, the trial, and the sentence (Hodgkin et al., 2007, p. 601). Based on its experience in reviewing the States Parties' performance, the Committee has indicated that even though detailed attention is paid to the rights of children and many efforts are undertaken to establish juvenile justice systems in compliance with the Convention, there is still a long way to go. Progress is needed in relation to:

- respect and enforcement of procedural rights

- development and implementation of measures for dealing with children in conflict with the law without resorting to judicial proceedings (diversion)

- use of deprivation of liberty only as a measure of last resort

- setting up of comprehensive juvenile justice policy and the undertaking of measures meant to prevent children from coming into conflict with the law

- systemic gathering of comprehensive statistical data in this field (UN Committee on the Rights of the Child, 2007a, paras. 2-3; van Bueren, 2005, pp. 1-3). 
Article 40 provides a list of minimum guarantees for the child and identifies a series of States Parties' obligations meant to ensure the fulfilment of these guarantees. Even though the Convention is a holistic treaty, there are two other Articles dedicated to children in contact with the criminal justice system: Article 37 and Article 39, which extend the protection enshrined by Article 40. Article 37 bans the death penalty and life imprisonment 'without the possibility of release' and requires that any deprivation of liberty must be used as a last resort and for the shortest appropriate time. Article 39 requires States Parties to adopt 'measures to promote physical and psychological recovery and reintegration of child victims' (Hodgkin et al., 2007, p. 601).

The final version of Article 40 codifies the core elements of the United Nations Standard Minimum Rules for the Administration of Juvenile Justice (The Beijing Rules). The initial draft of the article was less ambitious and merely reproduced the texts of the pre-existing international standards dealing with the administration of justice. However, the drafters of the Convention realised they had the opportunity of strengthening the attention on children's rights in justice administration and of raising the status of The Beijing Rules (soft-law provisions) (van Bueren, 2005, p. 5). ${ }^{1}$

In comparison with related international human rights treaties, many of the provisions contained in Article 40 are de novo. In other words, they mirror the content of other treaties, but with a stronger child rights approach. This is particularly evident for the following issues as main principles of the juvenile justice system. (van Bueren, 2005, p. 7):

- Minimum age of criminal responsibility

- Use of diversion

- Promotion of the child's sense of dignity and worth.

\section{General Principles}

Article 2 Based on the General Comment no. 10, States Parties must 'take all appropriate measures to ensure that all children in conflict with the law are treated equally' and special attention should be dedicated to vulnerable groups. Therefore, States Parties are requested to establish rules, regulations, and protocols to enhance equal treatment of child offenders and provide redress, remedies, and compensation.

Many children in conflict with the law are also victims of discrimination. Further discriminatory victimisation can affect former child offenders, trying to get education or work. States should intervene in order to prevent such discrimination and

\footnotetext{
${ }^{1}$ The United Nations Standard Minimum Rules for the Administration of Juvenile Justice (The Beijing Rules) were adopted by the General Assembly in 1985, while the Convention on the Rights of the Child was being drafted. The Beijing Rules provide relevant standards for the implementation of the Convention.
} 
provide former child offenders with appropriate support and assistance in their reintegration process into society, as required by Article 40 (1) (UN Committee on the Rights of the Child, 2007a, paras. 6-9). Moreover, criminal codes often contain provisions criminalising behavioural problems of children such as vagrancy, truancy, runaways, and other acts, which often are the outcome of psychological or socio-economic problems. These acts, 'also known as Status Offences, are not considered to be such if committed by adults' (UN Committee on the Rights of the Child, 2007a, para. 8). This is a form of discrimination that negatively impacts on children, particularly those belonging to vulnerable groups and poor households. ${ }^{2}$

Article 3 The principle of the best interests of the child is the basic concern of the juvenile justice system and it receives primary consideration in all decisions in this field. Furthermore, the specific physical, psychological, developmental, and educational needs of the child justify the necessity for a specialised juvenile justice system and a lesser culpability approach in the administration of justice for those in conflict with the law. Therefore, the protection of the best interests of the child implies the replacement of the traditional objectives of criminal justice, repression, and retribution, with the objectives of rehabilitation and restorative justice (UN Committee on the Rights of the Child, 2007a, para. 10, 2013, para. 28).

Article 6 Because of the negative impact of delinquency on child's development, States Parties should develop national programmes and undertake preventive measures meant to ensure the right to life, survival, and development of all children. Furthermore, this basic right should result in the state's policy responding to juvenile delinquency in ways from supporting the child's development to prohibiting the death penalty and a life sentence without parole (Article 37), and in which the deprivation of liberty, including arrest and detention, is used only as a measure of last resort and for the shortest appropriate period of time needed, as per Article 37 (b)) (UN Committee on the Rights of the Child, 2007a, para. 11).

Article 12 Throughout the juvenile justice process, the child must have the opportunity to express their views freely, and to those views should be given due weight in accordance with the age and maturity of the child (Article 12 (1)). 'He/she can be heard directly and not only through a representative or an appropriate body if it is in her/his best interests.' This applies to all stages of the process, such as the pre-trial 'when the child has the right to remain silent, as well as the right to be heard by the police, the prosecutor and the investigating judge', and also to the phases of adjudication, implementation of the sentence and imposition of measures (UN Committee on the Rights of the Child, 2007a, paras. 12, 43-45). For a comprehensive juvenile justice policy, based on the 'Riyadh Guidelines,' child participation should be furthered in governmental and non-governmental delinquency prevention programmes (paragraphs 3 and 9(h)) (Hodgkin et al., 2007, p. 609; UN Committee on the Rights of the Child, 2009, paras. 57-61).

\footnotetext{
${ }^{2}$ See Article 56 of the Riyadh Guidelines.
} 


\section{Articles Related or Linked to Article 40}

Article 13, since in order to fully participate during the different phases of the proceedings the child must be informed not only of the charges, 'but also of the juvenile justice process as such and of the possible measures' (UN Committee on the Rights of the Child, 2007a, paras. 47-48).

Article 16, right to privacy in connection with Article 40(2)(vii) (see below).

Articles 19, 32 and 34, as protection from all forms of violence and from economic or sexual exploitation during all the judicial and non-judicial process and the undertaking of the related measures.

Article 18 and Article 27, with reference to the importance of setting up a holistic policy on juvenile justice meant to

- promote the child's sense of dignity and worth

- to reinforce 'the child's respect for the human rights and fundamental freedoms of others' and

- to facilitate 'the child's reintegration and the child's assuming a constructive role in society' (Article 40(1)) and in the undertaking of some diversion measures (Article 40(4)).

Both these articles refer to the importance of the educational role of parents from prevention on to the reintegration, in line with the United Nations Guidelines for the Prevention of Juvenile Delinquency (the Riyadh Guidelines). ${ }^{3}$ General Comment no. 10 reiterates the importance of the responsibility of parents for the upbringing of their children, but at the same time, it asks States Parties to provide the necessary assistance to parents (or other caretakers) in the performance of their parental responsibilities and confirm the States Parties' duty to promote the social potential of parents also for the prevention of juvenile delinquency (2007a, paras. 15-20).

Article 20 and Article 25, in relation to alternative care measures and the periodic review of placement or treatment. The principles of these provisions apply to all forms of placement of the child outside the family context. This implies the undertaking of constant monitoring of children placement for the purpose of care, protection, or treatment, to assess the quality of the child's life and their harmonious and full development. In particular, in relation to Article 25, the Committee underlines that it applies to all sentences imposed upon children, for which 'the possibility of release should be realistic and regularly considered' (UN Committee on the Rights of the Child, 2007a, para. 77).

\footnotetext{
${ }^{3}$ United Nations Guidelines for the Prevention of Juvenile Delinquency (the Riyadh Guidelines) states: 'Measures should be taken and programmes developed to provide families with the opportunity to learn about parental roles and obligations as regards child development and childcare, promoting positive parent-child relationships, sensitizing parents to the problems of children and young persons and encouraging their involvement in family and community-based activities.' (UN General Assembly, 1991a, para. 16).
} 
Article 24, with reference to the access to health care and the highest attainable standards, in particular in relation to all the forms of institutional placement and the deprivation of the liberty of the child.

Article 28, with reference to the fact that often penal sanctions interrupt education, proper juvenile justice systems should avoid this by following the standard set by Article 40 (UN Committee on the Rights of the Child, 2007a, paras. 18, 23, 89).

Article 29, in relation to the most important goal of the administration of juvenile justice: the promotion of the full and harmonious development 'of the child's personality, talents and mental and physical abilities.' As also indicated in the Preamble and in Article 6 of the Convention, the child should be prepared to live a responsible life, assuming a 'constructive role with respect for human rights and fundamental freedoms' of others (UN Committee on the Rights of the Child, 2007a, para. 16).

Article 37 bans the death penalty and life imprisonment 'without possibility of release' and requires that any restriction of liberty must be used as a last resort and for the shortest appropriate period. It integrates, together with Article 39, the protection enshrined in Article 40.

Article 39 requires States Parties to adopt 'measures to promote physical and psychological recovery and reintegration of child victims', particularly important also in the reintegration of the child perpetrator of a crime. It also integrates, together with Article 37, the protection enshrined in Article 40.

\section{Relevant Instruments}

International Covenant on Civil and Political Rights (1966):

- Article 7(4), in case of detention, the 'detained shall be informed of the reasons for his detention and shall be promptly notified of the charge or charges against him'

- Article 10(2)(b), with reference to the necessity to determine the case 'without delay'

- Article 14(2)(b), in relation to the right of adults and children to defence and to a qualified legal assistance

- Article 14(3), with reference to the following rights:

- to be informed promptly and in detail about the nature and cause of the charges

- to have adequate time and facilities for the preparation of his defence

- to be tried without undue delay

- defence through legal assistance of his own choosing or if needed to have legal assistance assigned, and without payment in any such case where sufficient means are missing

- to have the free assistance of an interpreter if he cannot understand or speak the language used in court

- not to be compelled to testify against himself or to confess guilt. 
- Article 14(4) with reference to the necessity that the procedures concerning children should 'take into account their age and the desirability of promoting rehabilitation'

- Article 15(1) principle of non-retroactivity of the penal law

UN Standard Minimum Rules for the Administration of Juvenile Justice (Beijing Rules) (1985).

UN Standard Minimum Rules for Non-custodial Measures (The Tokyo Rules) (1990), are relevant to the implementation of Article 40(3)(b) and provide minimum safeguards for persons subject to alternatives to imprisonment.

UN Guidelines for the Prevention of Juvenile Delinquency (Riyadh Guidelines) (1990).

UN Rules for the Protection of Juveniles Deprived of their Liberty (Havana Rules) (1990).

American Convention on Human Rights 'Pact of San Jose, Costa Rica' (B-32) (1978), Article 5(5), states: 'Minors while subject to criminal proceedings shall be separated from adults and brought before specialised tribunals, as speedily as possible, so that they may be treated in accordance with their status as minors'. This Article imposes a stricter States Parties' obligation to bring accused children before of a specialised tribunal, whereas Article 40(3) asks States Parties 'to seek to promote the establishment of laws, procedures, authorities, and institutions specifically applicable to children' (van Bueren, 2005, p. 8).

African Charter on Human and Peoples' Rights (1981), Articles 17 and 30, do not incorporate the States Parties' obligation to set up specialised juvenile justice institutions.

Guidelines of the Committee of Ministers of the Council of Europe on child friendly justice (2010).

\section{Attributes}

\section{Attribute One: Specialised Juvenile Justice System and the Related Comprehensive Policy (Article 40(1) and (3))}

Article 40 (1) introduces the main innovative aspect of this article as the 'principle of children's rights approach to the administration of juvenile justice.' It sets the fundamental principles guiding the treatment of children in conflict with the law and, as explained in General Comment no. 24, suggests that the treatment is consistent with the age of the child and with the child's sense of dignity and worth. Furthermore, it should have an educative aim, meant to reinforce 'the child's respect for the human rights and fundamental freedoms of others' and to facilitate 'the child's reintegration and the child's assuming a constructive role in society' (UN General Assembly, 1991b), which is consistent with Article 29 of the Convention (UN Committee on the Rights of the Child, 2019, para. 15). 
Article 40(3) requires States Parties to promote the setting up of a specialised juvenile justice policy and systems to be applied to children alleged as, accused of, or recognised as having infringed the penal law. This requires the establishment of dedicated laws, procedures, authorities and institutions such as specialised police units, judiciary, courts system, prosecutors' office and the provision of specialised defenders or other representatives for children and specialised services such as probation, counselling or supervision along specialised facilities, for example day treatment centres, facilities for residential care and treatment of child offenders (Hodgkin et al., 2007, p. 616; UN Committee on the Rights of the Child, 2007a, paras. 30-31, 90-95). ${ }^{4}$

\section{Attribute Two: Fair Trial Principles for Children (Article $40(2))$}

Article 40(2) identifies the main States Parties' obligations to ensure to the child the benefit of the principle of non-retroactivity of the penal law. This principle is as also mentioned in Article 15(1) of the International Covenant on Civil and Political Rights and from which no derogation is permitted (van Bueren, 2005, pp. 13-14).

Article 40(2)(a)) lists the legal rights of children alleged or accused of having committed a crime. Those include the following:

- Respect for the principle of the presumption of innocence. This equally applies to adults and implies that according to the law a child is innocent until proven guilty (Article 40(2)(b)(i)) (van Bueren, 2005, p. 14)

- The right be informed promptly and directly of their charges and to have appropriate assistance in the preparation and presentation of their defence (Article 40(2)(b)(ii)) (van Bueren, 2005, pp. 14-15)

- If the case has not been diverted away from the juvenile justice system, the right to benefit from the 'principle of equality' before the law (Article 40(2)(b)(iii)). This implies:

- The right to see their case determined by a competent 'independent and impartial authority or judicial body', including administrative bodies. The broad formulation is meant to reflect the diversity of juvenile proceeding available throughout the world.

- The right to 'have the matter determined without delay, in a fair hearing according to the law.' This is also emphasised in Article 10(2)(b) of the International Covenant on Civil and Political Rights.

- The right to benefit from the presence of legal or other appropriate assistance 'unless it is not considered to be in the interest of the child', through a

\footnotetext{
${ }^{4}$ See also Beijing Rules, Rule 2 (3) and A Commentary on the United Nations Convention on the Rights of the Child, Article 40: Child Criminal Justice (van Bueren, 2005, pp. 25-26).
} 
well-trained, informed, and independent body whom the child can rely on and feel confident with. ${ }^{5}$ This should allow the child to participate directly or indirectly in the procedure, in the full exercise of Article 12(2) of the Convention on the Rights of the Child and Article 14(2)(b) of the International Covenant on Civil and Political Rights (van Bueren, 2005, pp. 15-20).

- The right to remain silent and to not be obliged to give testimony or to confess guilt (Article 40(2)(b)(iv)). This mirrors Article 13(4)(g) of the International Covenant on Civil and Political Rights and Article 11 of the Universal Declaration of Human Rights. However, to be precise, the right to silence as a basic procedural safeguard is found only in the Beijing Rules and in General Comment no. 10. It is foreseen because children are more vulnerable to pressures to confess and the right to silence might help them to limit or prevent such pressure. Therefore, this silence should not be interpreted as supporting the finding of guilt (Hodgkin et al., 2007, p. 613; UN Committee on the Rights of the Child, 1995, paras. 20, 34).

- In case the child is convicted, they have the right to appeal and to see their conviction and sentence reviewed by a higher tribunal in line with Article 14 (5) International Covenant on Civil and Political Rights (Article 40(2)(b)(v)) (UN Committee on the Rights of the Child, 2007a, paras. 23-24, 2019, para. 57).

- In circumstances where the child cannot understand the language used, they have the right to have the free assistance of an interpreter. This applies to a court trial as well as to all stages of the juvenile justice process and implies that the 'interpreter has been trained to work with children.' The child's use and understanding of their birth language might be different from that of an adult. In line with Article 40(2)(vi), and in accordance with the special protection measures attributed to children with disabilities by Article 23, the inability to understand the language must also be recognised in relation to children with speech impairment or other disabilities (UN Committee on the Rights of the Child, 2007a, paras. 62-63, 2007b).

- The right to full respect for the child's privacy. This reflects the right to protection of privacy enshrined in Article 16 of the Convention and it covers all stages of the proceedings from the 'initial contact with law enforcement (e.g., a request for information and identification) up until the final decision by a competent authority, or release from supervision, custody, or deprivation of liberty'. The provision mirrors the wording of Article 14(1) of the International Covenant on Civil and Political Rights and is expanded by the Beijing Rules (Rule 8(1) and (2)), with the intention to avoid harm caused by undue publicity, for example through press releases or a public hearing, because of its effect of stigmatisation, and possible impact on the child's ability to have access to education, work, housing, or to be safe (Hodgkin et al., 2007, pp. 615-616; UN Committee on the Rights of the Child, 2007a, paras. 64-65).

\footnotetext{
${ }^{5}$ The qualification of the child's representative as legal or non-legal is meant to underline that the juvenile's representative ought to be a well-trained, informed, and independent professional.
} 


\section{Attribute Three: The Establishment of the Minimum Age of Criminal Responsibility (Article 40(3)(a))}

Article 40(3)(a) asks States Parties to establish a minimum age of criminal responsibility (MACR). Based on the interpretation provided in its General Comment no. 24, the Committee has clarified that:

- Children who commit an offence under the specified MACR cannot be formally charged or held responsible in a penal law procedure (2019, para. 20).

- A MACR below 14 is not internationally acceptable. Therefore, the Committee recommends that States Parties should regard 14 as the absolute minimum and once a MACR is set no exception should apply, not even when serious offences are committed (2019, para. 21).

- If there is no reliable proof of age and it cannot be established, the child shall not be held criminally responsible (2019). ${ }^{6}$

\section{Attribute Four: The Diversion Process and Alternatives Measures to Institutionalisation (Article 40(3)(b) and (4))}

Article 40(3)(b) incorporates the principle of diverting children away from formal trial procedure whenever appropriate and desirable, 'providing that human rights and legal safeguards are fully respected.' The Committee's General Comment no. 24 clarifies that $(2019)^{7}$ :

- Diversion can be implemented when the States Parties have a variety of dispositions available such as care, guidance and supervision orders, counselling, probation, foster care, educational and training programmes, and other alternatives to institutional care.

- It should be proposed only where there is convincing evidence that the child has committed the alleged offence and voluntarily acknowledges responsibility without intimidation or pressure. ${ }^{8}$

- The child must freely and willingly consent in writing to the diversion.

- The completion of the diversion should result in a definite and final closure of the case (2019, paras. 16-18). ${ }^{9}$

\footnotetext{
${ }^{6}$ See also the Beijing Rules Rule 4 and its interpretation, General Comment no. 7 (2006, para. 36 (i)) and the Implementation Handbook (Hodgkin et al., 2007, pp. 616-617).

${ }^{7}$ See also the Beijing Rules Rule 4 and its interpretation, General Comment no. 7 (2006, para. 36 (i)) and the Implementation Handbook (Hodgkin et al., 2007, pp. 616-617).

${ }^{8}$ This acknowledgement must not be used against the child in any subsequent legal proceedings.

${ }^{9}$ The Beijing Rules expand on the use of diversion from judicial proceedings in rules 11, 14(1). See their official commentary (Hodgkin et al., 2007, p. 618).
} 
The United Nations Standard Minimum Rules for Non-custodial Measures (The Tokyo Rules) are relevant to the implementation of Article 40(3)(b). The rules provide minimum safeguards for all persons subject to alternatives to imprisonment. They do not include any specific reference to children, but state that they should be applied with no discrimination based on age. Article 40(3)(b) also provides a connection with Article 37(b) and the provisions of alternatives to arrest, detention, and imprisonment (van Bueren, 2005, p. 28).

Article 40(4) identifies the duty of States Parties to provide a variegated range of measures as alternatives to institutional care, in order to not give the impression that diversion is a cheap solution or that States Parties follow a one size fits all solution. Based on the Convention, the diversion procedures need to suit the personal needs of each child and they should be proportionate to the child's circumstances and the offence committed (van Bueren, 2005, pp. 22-23, 30-31). Article 37 completes the protection enshrined in Article 40(4) and emphasises that depriving children of liberty must only be used as a last resort and for the shortest appropriate period' and it also bans capital punishment, life imprisonment without possibility of release, and any cruel, inhuman or degrading treatment or punishment' (Pinheiro, 2006, pp. 216, 217).

\section{References}

de Pinheiro, P. S. (2006). Report of the independent expert for the United Nations Study on violence against children, A/61/299. UN. Retrieved November 12, 2020, from http://digitallibrary.un. org/record $/ 584299$

Hodgkin, R., Newell, P., \& UNICEF. (2007). Implementation handbook for the convention on the rights of the child (3rd ed.). New York: UNICEF. Retrieved September 21, 2020, from https:// digitallibrary.un.org/record/620060? $\mathrm{ln}=\mathrm{en}$

UN Committee on the Rights of the Child. (1995). Concluding observations: United Kingdom, February 15, 1995, CRC/C/15/Add.34. UN. Retrieved November 6, 2020, from http:// digitallibrary.un.org/record/198509

UN Committee on the Rights of the Child. (2006). General Comment No. 7 (2005) Implementing child rights in early childhood, September 20, 2006, CRC/C/GC/7/Rev.1. Retrieved October 12, 2020, from https://digitallibrary.un.org/record/584854? $\mathrm{ln}=\mathrm{en}$

UN Committee on the Rights of the Child. (2007a). General Comment No. 10 (2007) Children's rights in juvenile justice, April 25, 2007, CRC/C/GC/10. Retrieved October 12, 2020, from https://digitallibrary.un.org/record/599395? $\ln =$ en

UN Committee on the Rights of the Child. (2007b). General Comment No. 9 (2006) The rights of children with disabilities, November 13, 2007, CRC/C/GC/9. Retrieved October 12, 2020, from https://digitallibrary.un.org/record/593891? ln=en

UN Committee on the Rights of the Child. (2009). General Comment No. 12 (2009) The right of the child to be heard, July 20, 2009, CRC/C/GC/12. Retrieved October 12, 2020, from https:// digitallibrary.un.org/record/671444? $\mathrm{ln}=\mathrm{en}$

UN Committee on the Rights of the Child. (2013). General Comment No. 14 (2013) On the right of the child to have his or her best interests taken as a primary consideration (art. 3, para. 1), May 29, 2013, CRC/C/GC/14. Retrieved October 12, 2020, from https://digitallibrary.un.org/record/ $778523 ? \ln =$ en 
UN Committee on the Rights of the Child. (2019). General comment No. 24 (2019) on children's rights in the child justice system, CRC/C/GC/24. Retrieved November 29, 2020, from https:// tbinternet.ohchr.org/_layouts/15/treatybodyexternal/Download.aspx?symbolno=CRC $2 \mathrm{fC} \%$ $2 \mathrm{fGC} \% 2 \mathrm{f} 24 \& \mathrm{Lang}=\mathrm{en}$

UN General Assembly. (1991a). United Nations Guidelines for the Prevention of Juvenile Delinquency (The Riyadh Guidelines), 1990, A/RES/45/112. UN. Retrieved November 6, 2020, from http://digitallibrary.un.org/record/105349

UN General Assembly. (1991b). United Nations Rules for the Protection of Juveniles Deprived of Their Liberty, 1990, A/RES/45/113 (The Havana Rules). UN. Retrieved October 26, 2020, from http://digitallibrary.un.org/record/105555

van Bueren, G. (2005). A Commentary on the United Nations Convention on the Rights of the Child, Article 40: Child Criminal Justice. A Commentary on the United Nations Convention on the Rights of the Child, Article 40: Child Criminal Justice. Brill Nijhoff. Retrieved November 29, 2020, from https://brill.com/view/title/11607

Open Access This chapter is licensed under the terms of the Creative Commons Attribution 4.0 International License (http://creativecommons.org/licenses/by/4.0/), which permits use, sharing, adaptation, distribution and reproduction in any medium or format, as long as you give appropriate credit to the original author(s) and the source, provide a link to the Creative Commons license and indicate if changes were made.

The images or other third party material in this chapter are included in the chapter's Creative Commons license, unless indicated otherwise in a credit line to the material. If material is not included in the chapter's Creative Commons license and your intended use is not permitted by statutory regulation or exceeds the permitted use, you will need to obtain permission directly from the copyright holder.

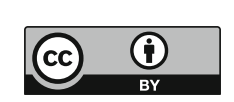

